\title{
The Politics of Classes of Labour: Reproduction Zones, Fragmentation and Collective Action in Karnataka, India
}

\author{
Accepted Pre-proof draft, 26 June 2018
}

To be published in Journal of Peasant Studies 45 (5), October 2018.

\begin{abstract}
Jonathan Pattenden. ${ }^{1}$
In the contemporary global economy, new technologies are growing the 'reserve army' of labour, while the wage-system is becoming increasingly unable to meet workers' 'basic needs'. Bernstein's concept of 'classes of labour' refers to the growing proportion of the world's population that is now compelled to reproduce itself through various forms of petty production, and wage-labour that is increasingly scarce, informal and precarious. Rather than more 'visible' locations in global production networks, this paper focuses on the underresearched majority of labourers who have little structural or associational power. Drawing on fieldwork in India, the paper seeks out the social, spatial and temporal forms of labour's collective action by analysing spatial patterns of reproduction and forms of control. Inflected with the agency of both capital and labour, these 'local labour control regimes' are shown to vary across two contrasting 'reproduction zones': a commuting zone that links villages to nearby cities, and a circulation zone that links remote villages to a distant city. The paper analyses how collective action varies across the two 'zones', and considers the possibilities for scaling up, consolidating and extending class struggle.
\end{abstract}

\section{Introduction: Bringing Politics into Classes of Labour}

In India, as elsewhere, the appropriation of land to extract raw materials for capitalist production, or territory for SEZs and other sites of industrial and tertiary production, has intensified (Borras et al. 2011; Levien 2011; Milne 2015). At the same time the dynamics of competitive accumulation and technological change are reducing levels of wage-labour (eg. Harriss et al. 2011). As rising underemployment grows the 'surplus population' (Marx 1976 [1867], 783), the bases of material reproduction become more spatially and temporally fragmented - especially for those who remain rooted in the countryside while commuting, migrating, and circulating for work (eg. Breman 1996; Swider 2015).

Most of India's more than 100 million migrants in 2016 were circular migrants (GoI 2017, 267), while millions commuted to work in nearby towns and cities. Around two-thirds of the rural-based population are landless or have marginal landholdings that are insufficient for material reproduction (GoI NSS 2013, 73; Pattenden 2016). Construction, the largest absorber of agricultural labour in India (Srivastava 2012, 76), will shed jobs as new technologies are developed, and older ones become more widespread. ${ }^{2}$ Along with the scattering of wage-work across sites and sectors (fragmentation in the sphere of production)

\footnotetext{
${ }^{1}$ University of East Anglia, UK. E-mail: j.pattenden@uea.ac.uk. The author would like to thank two anonymous reviewers for their comments, the editors of this special issue and of the Journal of Peasant Studies, those who gave up their free time to talk, Savitri for research assistance, and Radha and Shalmalee for translation. Thanks also to Gavin Capps, Demet Dinler and Yannis Feresiadis for comments on an earlier draft, and the members of the HMWDRS who provide a valuable forum for discussion.

${ }^{2}$ For example large ready-mix cement trucks are reducing demand for concrete pourers.
} 
comes a greater separation of workplaces from homeplaces (the spheres of production and reproduction).

These evolving dynamics of material reproduction raise questions about the politics of class relations and possible routes to improving labour's conditions through collective action questions that centre on the relationship between the 'structural power' that may be drawn from workers' locations in the economic system, and the 'associational power' that may be derived through workers' collective action (Silver 2003, 13; Wright 2000). This paper seeks to develop a framework for identifying the structural and associational power of the many Indian labourers whose material reproduction combines a continuing dependence on the agrarian (petty production and wage-labour) with non-agricultural work that is scarce, informal and precarious. Such workers are members of exploited classes who live and work in villages, commute, and circulate for work either seasonally or for years at a time. ${ }^{3}$ They are hard to organise and mobilise because of their greater spatial fragmentation across worksites, and widespread recruitment and organisation by labour intermediaries, which often renders vertical ties stronger than horizontal ones. Their frequent combination of wage-labour with various forms of petty self-employment can also undermine shared bases for collective action.

Bernstein's $(2006,455)$ term 'classes of labour' captures the fragmentation of labour across multiple sites of reproduction ('urban and rural, agricultural and non-agricultural wage employment and self-employment'), and is also concerned with fragmentation along lines of 'generation, gender, caste and ethnicity'. ${ }^{4}$ It points to the coexistence of exploitation and domination through insecure, informal and oppressive forms of reproduction. It underlines that in many places wage-labour is becoming increasingly scarce, growing the 'surplus population' and 'disciplin[ing] and disempower[ing] those in work' (Harriss-White 2005, 1243). And, in its reference to informality, it indicates the state's tendency to mediate labour relations in capital's favour. In other words it sketches the key impediments to classes of labour's structural and associational power. And yet it also indicates labour's potential political power by highlighting 'the growing numbers of those who 'depend - directly and indirectly - on the sale of their labour power for their own reproduction' (Panitch and Leys 2001, x cited in Bernstein 2006, 455), and who therefore share a position as members of the exploited classes. Although many members of classes of labour engage in forms of selfemployment, including farming, their households cannot reproduce themselves without wage-labour and are all net sellers of labour-power. ${ }^{5}$ This, despite the changing and complex lived experiences of fragmented processes of reproduction, suggests that it is as wagelabourers that classes of labour are most likely to act collectively in their interests.

\footnotetext{
${ }^{3}$ And in some cases includes those who have settled in the city but retain some social and economic links to their home villages - returning for marriages, and in some cases retaining small landholdings and bringing grains to the city.

${ }^{4}$ See also Lerche 2010 and Pattenden 2016 for discussion of classes of labour in relation to India.

${ }^{5}$ As net sellers of labour-power they either primarily reproduce themselves through wage-labour, or through petty forms of self-employment supplemented by wage-labour (where self-employment does not allow for simple reproduction let alone expanded reproduction). See below for the application of this definition to this paper's fieldwork areas. The term 'net sellers of labour power' (drawing on Patnaik 1976) does not capture the messiness of boundaries at the level of 'the concrete' as shown by discussions of petty commodity production and households' changing socio-economic position over time (Pattenden 2016), but nevertheless helps to pin down those households that primarily make a living through wage-labour.
} 
The term classes of labour, then, sketches various facets of fragmentation and political subordination, while indicating potential associational power. In order to deploy the term politically, classes of labour need to be analysed in actual social settings that draw out, for example, the co-constitution of class, caste and ethnicity (see, for example, Lerche and Shah, this volume), or gender, caste and class (Kapadia 1995). The broader literature on labour in an era of 'globalisation' and neoliberalism has pointed out how informality undermines the ability to mobilise in relation to the state, how precarity undermines the ability to mobilise in the workplace, and how recruitment through intermediaries undermines both (eg. Barrientos 2013). ${ }^{6}$ A countervailing recent literature on labour agency is skewed towards those workers who are integrated into global production networks in ways that accord them relatively more structural power, such as some of those supplying companies like Apple and high-street clothing stores (Brookes 2017; Zajak 2017), where international union and NGO networks have been able to exert some pressure through solidarity actions and/or the use of such mechanisms as core labour standards and international framework agreements (eg. Merk 2009). ${ }^{7}$

This paper draws on fieldwork data on members of classes of labour in the Indian state of Karnataka, of which over eighty per cent primarily make a living as wage-labourers - mostly in the agriculture and construction sectors (see below for details). As agricultural labourers they are scattered across remote fields working either individually or in small gangs for petty capitalists who exert various forms of control over them. ${ }^{8}$ As construction workers, with the exception of times when they have worked on a high-profile SEZ, they experience a highly fragmented labour process and frequent movement between worksites. In the words of a prominent south Indian construction union organiser, while 'in most sectors the product moves and the workers stay where they are, in construction the product stays where it is and the workers move' (interview, Chennai, May 2016). Construction workers are, then, not only more spatially fragmented, but there is also a temporal disjuncture between the labour process and the accumulation process, which undermines leverage. Accumulation takes place before workers arrive (through the appropriation of land), and after they have left - when the office blocks are occupied and the apartments are sold. Across India 97 per cent of construction work is informal (Srivastava and Jha 2016, 12), ${ }^{9}$ and over 90 per cent of workers are unorganised. ${ }^{10}$

In some contexts land is the primary issue for India's classes of labour - among, for example, those displaced by mining projects in the 'red corridor' that fans out north-eastwards from central India. More generally, retaining land is an issue for those with marginal landholdings due to its material, symbolic and socio-political value, but in most of India the capacity for

\footnotetext{
${ }^{6}$ The broader dynamics of the capital-labour relation allow lead companies in buyer-driven commodity chains to put downwards pressure on labour's terms and conditions as capitalists in the 'global south' struggle to access and hold on to a place in the global marketplace (eg. Barrientos and Kritzinger 2004), while capital's widespread ability to relocate can undo regulatory gains (Riisgaard and Hammer 2011), or spikes in associational power (Silver 2003) - spatial fixes offered across a broader terrain than was once the case.

${ }^{7}$ For a critical discussion of global labour studies literature, see Burawoy 2010.

${ }^{8}$ There are moments when labour's structural power increases - at harvest time, for example (Wilson 1999), although this can often be countered by drawing in labour from elsewhere.

${ }^{9}$ This is higher than the overall level of informality, which government data indicate stood at 91.9 per cent in 2011/12, down marginally from 92.7 per cent in 2004/5 but up in terms of absolute numbers by 14.62 million (Srija and Shirke 2014, 41).

${ }^{10}$ See Pattenden $(2016,43,76)$; Srivastava and Jha $(2016,86)$.
} 
land reform is limited to levels that will not meet the full costs of reproduction (Rawal 2008). Some small farmers joined the high-profile farmers' organisations of the 1980s and 1990s, but found their interests marginalised because the movements were led by the capitalist farmers who dominated and exploited them (Banaji 1994; Pattenden 2005). It will be argued here that the central political questions for India's classes of labour are focused on their role as wage-labourers - all depend on wage-labour (at least in part) to reproduce themselves, and many (a clear majority in this paper's fieldwork areas) primarily reproduce themselves through wage-labour. What, then, are the terms and levels of access to wage-labour, and how can classes of labour's material and political position be improved in a way that is not only sustainable in the face of counter-moves by capital, but which could lead towards more fundamental change?

The paper focuses on the fragmentation of labour in and around the workplace, and the mediation of the capital-labour relation by various types of contractors, which often has pivotal and contradictory impacts on associational power - dialectically-shaped differences that generate variations in experience and thinking that influence patterns of unity and division across workplace and living space. In addition, the paper discusses elements of state mediation of the capital-labour relation, outlines the role played by (pro) labour organisations, and touches on the characteristics of capitalists (levels of unity, and capacity to shape state processes and fragment labour). In other words it draws out variations in worker and capitalist unity (at the level of sites, sectors and networks); patterns and degrees of labour and capital's dependence on one another across time and place; the vulnerability of capital to loss of reputation/profit/market-share; and the state's contradictory mediation of the capitallabour relation: although fundamentally aligned with the interests of capital, it sometimes offers possibilities for labour to make material and political gains.

In order to deploy the term classes of labour politically, then, there is a need to analyse the diversity of 'concrete' capital-labour relations experienced by classes of labour. Such an attempt to pin down how and why the structural and associational power of precarious, informal and relatively invisible classes of labour varies across sites of production and reproduction requires the deployment of two further terms: local labour control regimes and reproduction zones.

\section{Local Labour Control Regimes}

If the term classes of labour points towards potential bases of unity among diverse processes of material reproduction, the terms local labour control regime and reproduction zone help to provide a framework for increasing understanding of who among informal classes of labour might mobilise, where, when, and how. Building on discussion in a previous paper (Pattenden 2016b), local labour control regimes (LLCRs) are understood here as an expression of class struggle in a particular place, and at a particular time. They centre on the relationship between simple and expanded reproduction in a particular place (how labourers make a living and how capitalists accumulate), which shapes geographies of dependence, and forms and degrees of exploitation and control (including rates of surplus value extraction and the degradation of human bodies (Marx 1976, 353)). LLCRs also encompass the ways in which a locality's economic activities are positioned in broader national and international markets (dynamics of competitive accumulation, and the capital-labour relation in general), ${ }^{11}$

\footnotetext{
${ }^{11}$ The reference to international markets draws on recent discussions with Elena Baglioni. See also Jonas (1996) for an earlier discussion of the term.
} 
and institutional mediations by socially produced actors such as the state (see also Burawoy 1985). These affect geographies of accumulation and reproduction (through the construction of irrigation canals or roads for example), the appropriation and distribution of resources, and the (non-)regulation of the capital-labour relation.

Inflected with the agency of capital and labour, LLCRs represent the concretisation of intraand inter-class relations. Under capitalism these relations render capital ascendant (hence 'control'), but to varying degrees - hence the need to analyse 'local' variations in order to map the distribution of structural and associational power. Burawoy's $(1985,88)$ typology of factory regimes, which were characterised by 'the labour process, market competition among firms, the reproduction of labour power, and state intervention', facilitated such a mapping showing, for example, how the geography of collective action in early twentieth century Russia was shaped by the different ways in which spatial dynamics of production, reproduction, location in markets, and state intervention played out across St Petersburg and Moscow (102-113). While factory regimes combined analysis of the 'political effects of the labour process' and the 'institutions that regulate and shape struggles in the workplace' (87), LLCRs represent an attempt to respond to increased spatial fragmentation of sites of reproduction by foregrounding the predominant forms of the capital-labour relation across particular villages and urban localities.

\section{Reproduction Zones}

Local labour control regimes vary in form across reproduction zones. As reproduction becomes more multi-sited, the spatial disaggregation of LLCRs becomes increasingly necessary in order to facilitate the search for moments and locations of greater structural power, and possible transitions to associational power and political change. The term 'reproduction zone' underlines the dynamism of labourers' structural power, denoting all of the places where a household lives and works, as well as their broader world-historical locations. Analysing LLCRs across reproduction zones helps to outline how labourers' sociopolitical position changes as they move across living spaces and worksites that are differentially located in relation to more specific and more general forms of the capital-labour relation (encompassing, in other words, particular production sites and their location in the world-historical economy), intra-class relations (especially patterns of social and spatial fragmentation and unity), and in terms of their mediation by socially produced collective actors - primarily the state.

If material reproduction is increasingly fragmented both spatially and temporally then it follows that class struggle cannot be imagined in terms of single locations, issues or fronts, but in relation to 'reproduction zones' as a whole. The forms that such struggles take are likely to reflect the spatial and temporal fragmentation of labour's reproduction by being more fluid, episodic and multi-sited.

In her vivid ethnography of construction workers in Beijing, Swider (2015) shows the interplay between workplace control, the spatial dynamics of production and reproduction, and the varying and uneven forms of collective action by migrant construction workers. Those living in the 'city of walls' work on large building sites populated by male migrant construction workers managed by sub-contractors, and divided by task and place of origin. They live in on-site dormitories, which facilitates tighter control and a lengthening of the working day. At the same time workers are constantly engaged in 'everyday' forms of class struggle (Scott 1985). They restrict work intensity by footdragging, engage in acts of theft and sabotage, and physically rein in abusive contractors. They also use time crunches to press 
claims over conditions, and when wages have gone unpaid workers have occupied cranes and threatened suicide. These dramatic protests are fast-tracked through social media to increase leverage on reputation-sensitive employers. Such actions are short-lived but widespread. They are also collectively planned and executed, and hard to counter because, unlike drawnout site or sector-based union campaigns, the organisation involved cannot be co-opted. As worker Li put it 'if there is no hand, the glove does not work' (Swider 2015, 122).

In order to better understand such forms of action, there is a need to analyse entire zones of reproduction because as workers move between sites their structural power varies. This may be manifested in moves between 'everyday' and overt forms of worker 'agency' (concrete acts by workers in their individual or collective interest), or between hidden and public transcripts (Scott 1990). A greater prevalence of 'public transcripts' through which workers openly articulate their views indicates a shift from a latent potential for action by virtue of objective conditions and shared experiences of domination and exploitation, towards concrete collective action (eg. Pattenden 2016, 83).

\section{Class Struggle}

Despite a relative absence of structural power, classes of labour do act collectively at times, ${ }^{12}$ and, it will be argued, increasingly through spatial and temporal forms that are different from the sustained place-based mobilisations that still fill the left's imagining of labouring class mobilisation. As a location of struggle, production sites have not necessarily become less important because the material reproduction of the labouring class has been stretched spatially and temporally. Instead the workplace is integrated into class struggle through different spatial and temporal forms. This is not to deny that there has been some displacement of struggles from workplace to living space, which is also part of the capitallabour relation writ large (see below), or that there is a need to expand the focus on the appropriation of nature (Baglioni and Campling 2017; Moore 2015), and the sphere of reproduction (Mezzadri 2016).

Class struggle is ever-present in capitalist society: in terms of who can access and control natural resources and appropriate its uses; in the sphere of reproduction over the time and energy spent (mostly by women) in preparing and restoring labour's capacity to be exploited; in the sphere of production over the intensity and length of necessary and surplus labour time; in the sphere of circulation of money and commodities (up to the moment of consumption) over the appropriation of surplus-value before and after the production process; and in terms of how the state accrues and distributes revenues based on natural resources and the extraction of surplus value.

Perpetually present, class struggle has a continuum of forms. At one end are the nonconfrontational 'everyday' acts that negotiate the margins of surplus-value extraction and the management of domination - such as petty theft, foot-dragging, and the shaping of public and hidden transcripts. At the other are varieties of sustained overt mass actions, and in between a variety of hybrid and changing forms. And, in addition to the main protagonists, a range of contemporary and historical actors mediate the dynamics to different degrees. As well as a variety of forms, class struggle encompasses different scales, and spatial and temporal patterns. Spatial patterns span from the highly localised to the globally networked, and from networks that coordinate struggles across place to networks that coordinate struggles in

\footnotetext{
${ }^{12}$ See, for example, Agarwala 2013 for discussion of more formal and overt forms, and Swider 2015 for more informal and less visible forms.
} 
particular places. Temporal forms extend from sustained bouts of struggle to episodes and moments that recur with varying degrees of frequency.

This schematic list matters when analysing the political and material position of informal labourers with relatively little structural power. These workers are not located in parts of the world economy where capital is made relatively vulnerable by virtue of restricted access to raw materials, the nature of its production sequence, especially time-sensitive integration into commodity circuits, or because high street prominence makes it reputation-sensitive. This is a paper about places where the particular forms of capital-labour relations leave labour particularly vulnerable; where a labour-centred development is as elusive as it is necessary.

This is a conundrum of labour-centred development (Selwyn 2014). Most informal labourers are located within the (social) relations of production in ways that usually militate against open collective forms of collective struggle, particularly in its more direct forms. As a rule, the worse that labour's material and political conditions are, the harder it is affect a labourcentred development, and the more urgent the analysis of local labour control regimes and reproduction zones becomes.

\section{Methodology and Reproduction Zones}

The paper draws on recent and long-term fieldwork in two south Indian districts and the city of Bangalore (see map). Fieldwork was first conducted in Dharwad district in 2002, and at various intervals since - most recently in August 2017. Additional interviews and surveys were conducted in 2008, 2010, 2013, and 2014 (further details of earlier research can be found in Pattenden 2016). Fieldwork was first conducted in Raichur district in 2007, and interviews and surveys of particular hamlets/villages were carried out in 2007, 2008, 2010, 2011 and 2014. In 2016 and 2017 additional interviews were carried out in two villages (Kamlapur in the commuting zone and Jagalwara in the circulation zone), in Bangalore offices, building sites, a colony of concrete workers (Yadgir colony), and an informal settlement populated by migrant construction workers. Interviews were conducted with helpers, masons, various types of 'maistries' (subcontractors, ${ }^{13}$ small-scale labour contractors, and petty capitalist small building contractors), house owners, a Building Company Managing Director, NGOs, union activists, and labour department officials. The initial research was ethnographic, and some of the recent fieldwork involved discussions with long-term key informants. The paper's recent empirical basis is, though, relatively limited, and its primary purpose is to contribute methodologically to the study of the politics of classes of labour.

The paper compares two reproduction zones of classes of labour (see Map). Both have two main sites of wage-labour (the village and the city), and in both cases the major sectors are agriculture and construction. Waves of mechanisation, shifts in cropping patterns, droughts and falling water tables have reduced the availability of wage-employment. As of 2014 the use of combine harvesters, long established in wetland villages, was slowly becoming more widespread in the dryland villages in the commuting zone. Transplantation machines, which would displace the single largest source of female agricultural labour in wetland villages, were being trialled.

\footnotetext{
${ }^{13}$ Depending on scale of operations and ownership of means of production, some subcontractors were petty capitalists, and some were labour organisers who sometimes worked alongside workers.
} 


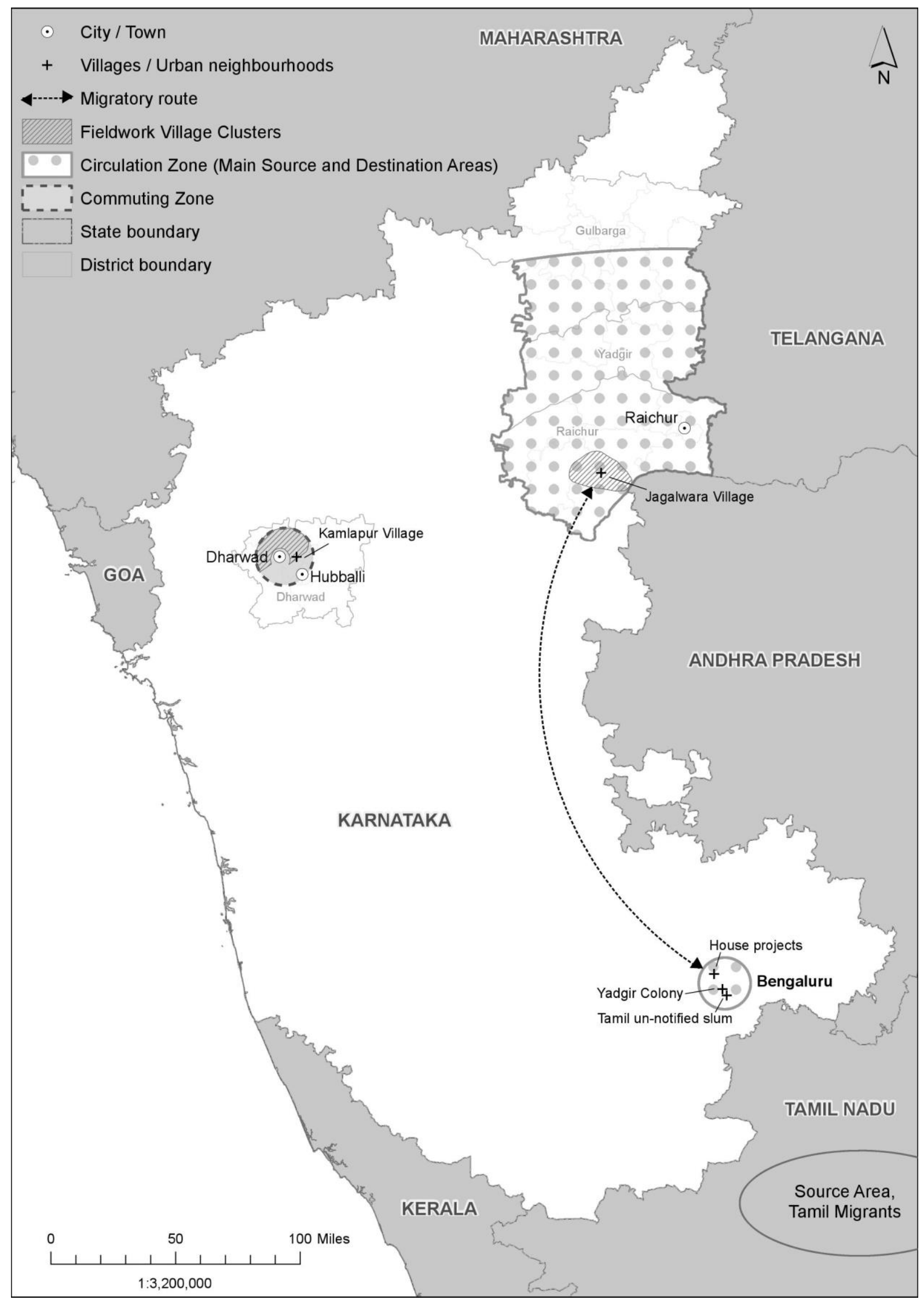

Map of Fieldwork Areas by Eseld Imms 
The two reproduction zones are distinct in various respects including distances between home villages and urban worksites, and levels of economic dependence on the village (see Table 1). The first zone is a commuting zone that encompasses the medium-sized city of Dharwad and nearby dryland villages. The closer villages are more tightly integrated into the urban economy, as are those with poorer soils, which tend to reduce agricultural profitability and foster diversification of the bases of simple and expanded reproduction (how labourers make a living and how capitalists accumulate). In Kamlapur village most male labourers commuted to the city to work on small construction projects, while most female labourers remained in the village as agricultural labourers. Less than fifteen per cent of households belonging to classes of labour primarily made a living through petty commodity production (see Table 1). Most primarily made their living through informal urban wage-labour, ${ }^{14}$ and were largely economically independent of the village. This had eroded the power of dominant caste landowners, although they retained disproportionate influence over village councils.

The more remote circulation zone centres on villages in southern Raichur district - part of a larger region with high levels of migration to the distant city of Bangalore. The circulation zone had higher levels of irrigation, greater agricultural profitability, and more marked forms of control over labour - evidenced by greater levels of 'indebtedness' to farmers, and more cases of bonded labour (see Pattenden 2016 for a more detailed account). As in the commuting zone village, most households primarily made a living through informal wagelabour, although here it was mostly as agricultural labourers (see Table 1). ${ }^{15}$ Mechanisation and drought increased migration to Bangalore's building sites in the early 2000s. All or part of most labouring households have migrated at some point, with some migrating seasonally, but most (especially the landless) migrating for a number of years, with occasional visits home. Construction workers circulating to Bangalore were more tightly controlled at the workplace than those in the commuting zone because they were further from home, and more restricted to particular sites.

Table 1 Primary Bases of Reproduction of Households belonging to Classes of Labour in the two Reproduction Zones (source: fieldwork data)

\begin{tabular}{|l|l|l|}
\hline $\begin{array}{l}\text { Percentage of households } \\
\text { primarily reproduced through: }\end{array}$ & $\begin{array}{l}\text { Commuting Zone } \\
\text { (dryland), } \\
\mathbf{\approx 1 0} \mathbf{~ k m} \text { from the city. }\end{array}$ & $\begin{array}{l}\text { Circulation Zone } \\
\text { (part canal-irrigated), } \\
\mathbf{> 4 0 0} \mathbf{~ k m ~ f r o m ~ t h e ~ c i t y . ~}\end{array}$ \\
\hline Informal wage-labour & 82 & 84.9 \\
\hline $\begin{array}{l}\text { Petty farming and livestock- } \\
\text { rearing }\end{array}$ & 14 & 13.4 \\
\hline Agricultural wage-labour & 25 & 61.9 \\
\hline Urban wage-labour & 59 & 22.4 \\
\hline Construction wage-labour & 50 & 22.4 \\
\hline
\end{tabular}

\footnotetext{
${ }^{14}$ More precisely, of around the two thirds of households that belonged to classes of labour in 2014, only 14 per cent made a living through petty agriculture and livestock-rearing, while 82 per cent did so through informal wage-labour (Pattenden 2016b, 1819). Of these, 70.2 per cent mostly worked in the nearby city and 29.8 per cent in the village.

${ }^{15}$ In 2014, of the approximately 70 per cent of households that belonged to classes of labour in Jagalwara village, 84.9 per cent primarily reproduced themselves through informal wage-labour while 13.4 per cent primarily did so through agriculture and livestock-rearing (Pattenden 2016b, 1819). 73 per cent of the predominantly wage-labouring households primarily made a living as agricultural wage-labourers in their own and nearby villages, while 27 per cent primarily did so as construction labourers in distant Bangalore.
} 


\section{Fragmentation, Management and Mediation}

The remainder of the paper compares the zones primarily in terms of three key aspects of local labour control regimes: fragmentation, management, and mediation by the state. ${ }^{16} \mathrm{With}$ regard to the first of these, classes of labour were not only spatially fragmented across cities and villages, they were also fragmented within the various production sites across their reproduction zones (by gender, task, experience, wage etc.). Within agriculture tasks were divided by gender (women put and pull things from the earth, while men spray, operate machinery and steer oxen), and carried out individually or in groups. In construction, meanwhile, women remained in 'unskilled' positions, were paid around one third less than men for equivalent work, and managed by men. Sexual harassment was endemic, and resistance was often punished with heavier loads.

Construction labour is fragmented horizontally as well as vertically. While wall construction, plastering and concrete curing is done by core workers who remain on site for the duration of a project, excavation (usually now done by JCB), 'centreing' (temporary internal scaffolding), bar-bending, and concrete pouring are all-subcontracted along with electrical and plumbing work, tiling, glazing and painting. Across the two zones it will be shown that the skilled masons in the commuting zone had the greatest amount of structural power because they were the least economically dependent on their villages and the most depended upon by their maistries - a term applied to piece-rate gang leaders in agriculture, and a variety of labour intermediaries in construction including labour contractors, petty capitalist contractors, and subcontractors. ${ }^{17}$

The second element of LLCRs discussed here concerns the type of maistry managing labour, and how this shapes integration into the broader production process. Maistries are often critical to labour's capacity to act collectively, depending on whether they are closer to labour or capital (in terms of interests, dependence, and socially), and whether they are petty capitalists or managers-cum-workers. There were two main types of construction maistries in the fieldwork sites: petty capitalist contractor maistries who take care of materials as well as labour (and whose profits rise with the intensity of work and the lowering of wages), and labour maistries who take a cut of the wages of the labourers that they deploy, but who are also wage-earners and broadly aligned with the workers that they manage and occasionally work alongside. The distinction is critical for class position (Van der Loop 1996), their relationship to workers, and their location within class struggle (Wetlesen 2016). Across the two zones it will be shown that labour contractors on larger Bangalore sites run by more reputation-sensitive capitalists were best-placed to organise collectively.

The third aspect of LLCRs focused on here is their mediation by the state and pro-labour organisations. State interventions will primarily be discussed in relation to the homeplacebased provisions of the village council and the workplace-based provisions of the Buildings and other Construction Workers Welfare Board, which was also the primary focus of unions and pro-labour NGOs. It will be shown that the Welfare Board was the most likely site of collective action in the commuting zone, while the village council was the most likely in the circulation zone.

\footnotetext{
${ }^{16}$ The paper focuses primarily on urban worksites and their links to home villages. For more detailed discussion of rural worksites, see Pattenden 2016.

${ }^{17}$ Subcontractors may be higher-paid labourers or petty capitalists depending on scale of operation, ownership of machinery etc.
} 


\section{Local Labour Control Regimes in the Commuting Zone.}

In the commuting zone village, most male labourers worked on construction projects in a nearby city. Agricultural labour was now largely done by women, and increasing control over female labourers was shown by their very low wages - still only 100 rupees per day in 2017 , which was lower than wages in the circulation zone, and around two and a half times less than those earned by female construction workers. Commuting male construction workers worked mostly on small building projects (houses and small commercial developments) as core building labourers. They were divided almost equally between masons and helpers, and often organised into small tight sub-groups of four or six. Across the commuting zone workers were usually drawn from the maistry's home and nearby villages through kinship and other networks, and typically worked for the same maistry for years - particularly the more skilled among them. Meanwhile, concreting and other subcontracting gangs were mostly made up of workers who lived in the city.

While it seemed at first that core workers were divided between 'skilled' masons and 'unskilled' workers, there was in fact more of a continuum. There were more and less skilled masons and helpers, and 'second circle' masons who got work less regularly. Then there were helpers who moved between maistries, and irregular unskilled helpers who worked in the sector seasonally or when drought pushed them out of the fields. The most desperate waited at one of two labour markets in Dharwad city. Those from more distant villages had less bargaining power as they had already invested more time and money in getting there.

Different types of construction workers responded in very different ways when asked about the potential for collective action to demand better conditions, higher wages or greater access to social security. One type stood out through qualitatively different responses that underlined that they were the most likely to mobilise: the more experienced and skilled masons that maistries depended upon as the lynchpins of the labour process, particularly in the latter stages of house construction when the finer details were executed.

More experienced masons strategized and acted collectively to push up wages when the cost of living rose. They would take it in turns to tell the maistry about small wage increases on other sites. If that did not work then they might force the maistry's hand by floating the idea of going to work elsewhere. Such informal wage bargaining was, though, linked to periods of marked inflation rather than to pushing up real wages.

The relaxed way in which regularly employed experienced masons spoke about their work was telling, and in marked contrast to a younger 'second circle' mason who said that if he asked for a pay rise he would be 'told to take a holiday'. Helpers were equally circumspect. They faced greater competition for work, and were relatively easy to replace. Among construction workers, then, the lower levels of precarity provided by higher skill levels were central to structural and informal associational power. Such forms of power were, though, held in check by broader structures.

The type of maistries that skilled masons worked for shaped their ability to act collectively. There were eight construction maistries in Kamlapur village - four petty capitalist contractors, and four labour contractors. The latter supplied small teams of masons and helpers to small house-building sites and commercial developments operated by engineerscum-contractors. Although broadly aligned with labour their positionality was complicated by dependence on the capitalist engineers-cum-contractors who they generally worked for on a long-term basis. Relationships were relatively personalised, and in some cases engineers 
provided labour contractors with 'gifts' to garner loyalty and intensify the labour process. Those working under these labour maistries were in a more precarious position and unlikely to rock boats.

Those working for the village-based petty capitalist contractors who worked directly for house-owners in the city were in a somewhat stronger position, but even they would be reluctant to move against those that they depended on for work. Besides sporadic pushes for wage increases, they would need to work with petty contractors rather than against them in order to improve the terms of building contracts, but the constraints faced by petty contractors pushed them towards state-oriented forms of action.

The balance of power between petty contractor and owner was more skewed where the former was less well-established (see also De Neve 2014). House owners sometimes delayed payments and pushed up costs with last-minute demands. One petty contractor from Kamlapur related how the initial estimate of the costs of a housebuilding project was done in an office where people 'write fast', and that he had no basis for renegotiating when owners added in time-consuming details in the latter stages of a build, which, like delayed payments, pushed down his income. 'We cannot read and write', he said, 'but we can think and talk'. There was no petty contractors' association to defend his interests, and if there was a dispute with an owner he yielded more ground because he feared for his reputation in the relatively small market place of a provincial city. Larger and more established contractors could more easily absorb losses on one project and make up for them elsewhere, while in Bangalore reputations were more easily left behind.

A shift in the balance of power between construction workers and house-owners would require not only the unity of those working under particular maistries, but unity among maistries - hard to achieve as some would break ranks for the extra jobs that were on offer unless there was concerted organisation by unions. So, among the labour contractors and petty contractors from Kamlapur village, personalised forms of control, competition, and the informality of contractor-owner relations all cut against collective action in different ways. In addition labour was fragmented into small groups, as well as being divided between 'core workers' and an array of subcontracting gangs.

Apart from skilled masons' informal wage bargaining, the most likely focus of collective action were government welfare programmes. Male construction workers had little interest in the various programmes run by the village council (housing, employment etc.) because they wished to complement their relatively recent economic independence from the village by asserting their autonomy from the village's main political institution, which they saw as the domain of dominant caste landowners. In contrast, female agricultural labourers continued to view village-level government institutions as the primary target for claim-making, but were hampered by patriarchy and material dependence on farmers.

Relatively cohesive in caste terms, dominant class farmers have used their control over the allocation of welfare programmes through village councils to maintain their power and divide labour (Pattenden 2016). Rather than village councils, the most likely site of action was the workplace-based Building and other Construction Workers Welfare Board, which provided such things as compensation for death and disability, and grants for weddings and education. Skilled masons knew that the Board had collected millions through cess payments, but did not see it as worth the cost of registration because they did not expect the benefits to actually be paid after some workers had registered and received nothing. There was a need for a union 
or pro-labour NGO to counter co-option by particular dominant class interests, and prise the fund open. Such organisations were active in Bangalore, but not in the smaller city in the commuting zone. Were the money to begin to flow, skilled workers would lead the push for implementation.

\section{Local Labour Control Regimes in the Circulation Zone}

Local labour control regimes in the circulation zone had three key features. The first was the tight form of control exercised over agricultural labour in the home area. The second was the varying power of labourers across large and small construction sites in the city - greater on the bigger sites from which they were increasingly displaced by larger construction capital's preference for more pliant out-of-state migrants. The third key feature was the distance between village and urban worksite, which meant that workers lived in the city for long periods, usually in tents located on or near their worksites. This spatial fragmentation and the temporary nature of their urban dwelling sites undermined their political position in the city and channelled their power into collective moves for greater access to government resources in their home village.

Labourers who remained in the village were primarily engaged in scarce, informal and precarious agricultural work and were tightly controlled. There was widespread indebtedness to capitalist farmers (Pattenden 2016), who also found ways to control labour working on a piece-rate basis. The most significant form of piece-rate wage-labour, paddy transplantation, was managed by 'maistries' - in this case leaders of work-gangs who negotiate with farmers, manage the labour process, and distribute wages. With piece-rate arrangements daily incomes increase with the intensity of work, which encourages self-disciplining, shorter breaks and the exclusion of slower workers. Farmers exercised control by paying maistries more, lending them money, and providing other family members with more days of casual labour. In return labourers were dispatched to the fields in a timely fashion, and the gang leader sometimes agreed to small extensions of the area to be covered (a concealed reduction of the wage rate). In other words, proximity to employers forestalled the possibility of agricultural maistries pressing for improved conditions.

Those migrating to the city had had some experience of collective action on worksites. In twenty years working on Bangalore's construction sites, labour contractors from Jagalwara village had experienced three moments of collective action - all related to delayed wage payments, and all on large building sites run by and for well-known developers and builders. On these larger sites in Bangalore, there was some potential for labour subcontractors to coordinate collective action because of their greater proximity to labour than capital. Labour contractors here were unencumbered by personalised relations with capitalist employers, and lived alongside the labourers with whom they shared an interest in maximising wages and improving conditions. But labour contractors also indicated the fragility of such forms of collective action, alternating during interviews between being bullish about making demands about wages and living conditions, and stating that it was better not to 'make problems' and indicating the difficulties of uniting the various subcontractors.

As well as greater unity between labourers and their immediate managers, larger developers and builders are more reputation-sensitive. They do not wish to be found breaching core labour standards during a build. Given that clients include world-renowned brands like Phillips, they are also potentially vulnerable to such companies not wanting to be associated with buildings where core labour standards had been breached - assuming that could be shown given that construction workers leave before high-profile tenants move in. 
This relative vulnerability has pushed larger builders to increasingly hire out-of-state, mostly north Indian, migrant workers over the last decade. They were seen as 'more reliable', and unencumbered by families that create regulatory headaches around crèches and child labour. Of 600 workers manning a large high-end residential development in mid-2017, all were men and barely one per cent were in-state workers. In other words on more reputation-sensitive sites where construction workers have greater structural power, workers are more likely to be from out-of-state and have fewer political resources at their disposal.

The in-state migrants in this paper's circulation zone had largely moved from high-profile large projects for high-end residential developers and office blocks in SEZs, to smaller projects where the management structure afforded them less structural power: they were more atomised and there was no potential for joint action across subcontractors' gangs. As a rule wages were higher, but the living conditions were worse, the work was harder and the hours longer - especially if workers lived on site. Far from home, even the more experienced masons indicated a reluctance to make claims. They were loyal to and dependent on their maistries (labour contractors) who, in their turn, were dependent on building contractors and engineers. As labour's capacity for collective action grows, then, capital undermines it by modifying the way it is integrated into the production process.

Meanwhile settled migrant workers like those in Yadgir colony in south-central Bangalore who were more embedded in the city had shifted from being 'core construction workers' (masons and helpers) to subcontracting work where they moved from site to site on a daily basis. ${ }^{18}$ They competed for jobs rather than cooperating, and made few lasting connections with building contractors. Compared to core construction work, the work was less intense and less dangerous (particularly for women), the hours shorter, and the wages higher. Greater workplace autonomy had increased the scope for collective action, but the highly atomised nature of subcontracting work left no scope for it. Recent restrictions on river-sand mining and a growing influx of concreting lorries had further intensified competition, pushing workers employed by smaller operators into auto-driving and cleaning.

Unlike those who remained in Jagalwara village as agricultural labourers, those returning home from Bangalore were emboldened by reduced dependence on village landowners, and more likely to act collectively. With the support of a local social movement ${ }^{19}$ they had made claims for National Rural Employment Guarantee Scheme (NREGS) work from their village councils. In those villages where the balance of power was not too skewed to the dominant (generally in villages that were closer to the main roads, and with stronger connections to urban labour markets), welfare programmes provided a basis for collective challenges to the status quo - in contrast to the commuting zone. However, many labourers continued to circulate, and this greater spatial fragmentation undermined momentum.

\footnotetext{
${ }^{18}$ These workers, like the Tamil migrants referred to below, had settled in the city and did not intend to return home. Although not part of the circulation zone, they were part of what shaped it. Before moving into different parts of the construction sector, this earlier wave of migrants had previously occupied the small-scale core construction work that those in the circulation zone had now moved into.

${ }^{19}$ The Jagruthi Mahela Sanghathan.
} 
Table 2: Construction workers' most likely sites of collective action across the reproduction zones $^{20}$

\begin{tabular}{|l|l|}
\hline Location of Construction Labourer & Most likely site of collective action \\
\hline Commuting Zone, Dharwad & $\begin{array}{l}\text { Workplace in relation to petty contractors } \\
\text { (appeals for higher wages); workplace related to } \\
\text { state programmes (greater access to Welfare } \\
\text { Board funds). }\end{array}$ \\
\hline $\begin{array}{l}\text { Large Sites, Circulation Zone, } \\
\text { Bangalore }\end{array}$ & $\begin{array}{l}\text { Workplace in relation to large-scale capital (for } \\
\text { delayed/unpaid wages); homeplace related to } \\
\text { state programmes (for greater access to } \\
\text { government resources allocated by village } \\
\text { councils). }\end{array}$ \\
\hline $\begin{array}{l}\text { Small Sites, Circulation Zone, } \\
\text { Bangalore }\end{array}$ & $\begin{array}{l}\text { Homeplace related to state programmes (for } \\
\text { greater access to government resources allocated } \\
\text { by village councils). }\end{array}$ \\
\hline
\end{tabular}

\section{Mediation of Local Labour Control Regimes}

\section{State Mediation}

Local labour control regimes are shaped by a variety of institutional mediations - primarily those of the state. Poulantzas (1978) suggests that the state can best be understood as a social relation, and as a product and mediator of all social relations. Any attempt to understand how pro-labouring class change might be routed through the capitalist state has to begin by trying to understand how 'the class struggle, and especially political struggle and domination, are inscribed in the institutional structure of the state', how the state is situated 'vis-à-vis the field of struggle as a whole' (Poulantzas 1978, 49, 125), and how its appropriation and distribution of resources mediates and shapes the capital-labour relation.

Within worksites the potential for collective action is undermined by fragmentation, informality, precarity, the presence of a reserve army of labour, the cooption of some maistries, the lack of autonomy of others, and competition among them. Moving along the commodity chain from worksites was unlikely to be any more fruitful. The steel lobby and the sand (both coarser ' $M$ ' sand and finer river sand) and cement lobbies were hardly going to yield ground. Brick suppliers were mostly smaller-scale but still more powerful than petty contractors. ${ }^{21}$ Larger capital in the construction sector (both developers and builders), and associated industries like cement, wielded considerable political clout. Well represented by organisations like the Confederation of Real Estate Developers' Associations of India (CREDAI), they could also generally count on the support of state-level legislators who had made their way into politics via the sector. Many politicians develop passing and long-term links to major developers and builders, and in 2017 two state ministers were said to be strongly linked to two of the largest developers and builders.

\footnotetext{
${ }^{20}$ The settled workers living in formal housing (Yadgir colony) were mostly likely to act collectively in relation to the state (Municipal Corporation), as were the Tamil workers living in informal city settlements, but the latter were the least likely of all to act collectively.

${ }^{21}$ The small-scale village brick production sites visited during fieldwork were operated by petty village-based capitalists, while those in the city were subcontracted to intermediaries by larger capitalists.
} 
The power of capital within and beyond the sector, and the relative absence of worker contestation, contribute to the often high levels of profit in the construction sector (Levien 2011, 458; interview, Bangalore, September 2017). More generally, and beyond these more direct state-capital links, the state mediates the capital-labour relation in the construction sector in various ways. It regulates land use, draws informal funding from suppliers of sand and steel, loosely regulates workplaces (or perhaps more accurately, largely abdicates from its regulatory responsibilities), provides a smattering of social security, and subsidises workers' material reproduction in their home areas - primarily in the case of Karnataka through the Public Distribution System of subsidised foodgrains - while routinely denying migrant workers access to such programmes in destination areas.

The state's subsidising of part of labour's reproduction costs through employment and other programmes has contradictory implications for the capital-labour relation. It helps to maintain social stability, allows capital to lower wages, and strengthens its ability to compete in the global marketplace. But if it goes too far, and labour becomes too independent of capitalists - as began to happen in certain places when the NREGS was at its peak in the early 2010s - then there is a potential for labour to make socio-economic and socio-political gains that recalibrate the capital-labour relation in its favour.

From labour's perspective such gains may be temporary and individualised, and develop new faultlines among classes of labour by subsuming them within competitive populist regimes (Vijayabaskar 2016), or local-level clientilism (Pattenden 2011). In Yadgir colony in Bangalore, antagonisms had long been focused on the state, and initially these centred on collective claims for services. From the time when the number of these migrant workers' tents had swelled to the point when they were deemed to be a votebank by local politicians and given formal housing, claim-making had become increasingly individualised around Welfare Board grants and low-interest NGO loans. Tamil migrants living a few hundred metres away had not been so lucky. In the city for as long, their 25 rudimentary shacks meant that they were still few to be seen as a votebank, and in any case they were from a different state and spoke a different language.

The state mediates unevenly, and often in ways that generate individualised rather than collective forms of action that can divide labour politically without providing any sustained material gain. But if material gains pass a certain point and re-work the balance of power they may be locked in, and provide a platform for extending class struggle back to the work arena. In other words collective action in relation to the state can be, but tends not to be, incrementally transformative. For now, though, the relationship between labourers' struggles in the workplace and the 'living space' matters more than whether they are primarily expressed in one or the other arena.

Given the horizontal and vertical fragmentation of the small-scale construction sector, the political weight of larger construction capital, and the complications of petty capitalist accumulation, the most likely avenue for collective action by informal construction workers remains the state - at least in the short-term until sporadic moves against big capital are underpinned by strengthening networks and a generalised upwards tilt in informal labour's structural and associational power. South India's largest construction union of recent decades (the TKTMS in Tamil Nadu), supported by networks like the National Centre for Labour, ended up going down this very path mobilising for a Welfare Board that was neither against the interests of contractor maistries, nor of a state trying to keep labour costs down while 
growing the country's share of the global marketplace (interviews in Chennai and Bangalore, May 2016). And here, similarly to this paper's findings, it was the masons, and especially those located in commuting zones in and around district towns, who led the way.

\section{Mediation by Labour Organisations}

The main actual and potential forms of collective action identified across this paper's commuting and circulation zones related to wages and state welfare provisions (see Table 2). Besides occasional brief encounters between construction labourers working on small sites in Bangalore and unionists circulating information about the Welfare Board, none of the workers who are the subject of this paper had had any dealings with pro-labour organisations. Nevertheless, given that this paper seeks out possible routes to labour's increased structural and associational power it is worth briefly outlining the activities pursued by pro-labour NGOs and unions who work with construction labourers. Brief mention will also be made of a recent mobilisation by garment workers - a detailed assessment would require analysis of relations between workers, intermediaries, managers and unions, and so the point here is simply to underline that informal workers do mobilise en masse, but more sporadically, and through less formal types of organisation.

By employing north Indian workers who do not speak the state language, the strongest, and at the same time the most vulnerable sections of capital, made it harder for unions and NGOs in Bangalore to forge relationships with workers - already made difficult by the fact that workers on large sites lived behind security cordons. NGOs tended to work with construction workers who were settled in the city rather than migrant workers like the ones living in this paper's circulation zone. Unions have used tactics such as the circulation of multi-language leaflets to reach such workers, but made very few inroads due to 'worries about labour contractors and maistries'. Faced with such obstacles union activists have tried to reach workers through their home areas - both by visiting source villages, and by creating links with organisations working in those areas (interviews in Bangalore and Chennai, May 2016). For example, when a high-profile builder failed to pay workers' wages in early 2016 the issue was pursued through links established between Bangalore-based unionists and an organisation in the workers' home state of Jharkhand (interview, May 2016). ${ }^{22}$

Welfare Board registration is the single most significant basis of NGO and Union organisation of construction workers. Some see it as a way of building up labour's collective strength, and some see it as a means of building up their own strength. Others still see it as a way of making money through gatekeeping. Some unionists, though (generally those from independent unions or those associated with less established political parties), are less focused on maximising membership, and push back against fragmentation by emphasising workers' shared position as members of the exploited classes. They encourage workers to analyse their conditions, and also try to develop labour's awareness of its power by highlighting its fundamental role in generating the physical infrastructure that underpins India's economic growth (interviews, Bangalore and Chennai, May 2016). Such strategies go alongside actions around wages and working conditions, attempts to challenge precarity

\footnotetext{
${ }^{22}$ Such strategies resonate with calls in the literature for more emphasis on local trade unions, selforganised workers' groups, cross-organisational networks (Zajak et al. 2017, 899), 'worker centre'based 'local advocacy networks' (Milkman 2010, 4), and a 'social movement unionism' that spans workplaces and living spaces, and links different antagonisms and spatial scales (Waterman 1993).
} 
through collective action and legal channels, and the development of networks of mutual support and coordination.

As well as local and national networks, international allies have some role to play. Following pressure from Building and Woodworkers International, which has links to Indian construction unions, the Asian Development Bank has set the ILO's core labour standards as conditions for the release of loans, and the International Finance Corporation has outlined similar conditions. Union networks have called for all building contracts to have worker components based on those same international principles, and national legislation provides additional points of potential leverage. Larger capital is the most vulnerable to such offensives, and also the most likely to implement regulations.

In May 2016 the national government quite suddenly ruled that garment workers could not access the Provident Fund (a form of social security based on employer and employee contributions) until the age of 58. It thereby pushed out of reach the funds that could pay for a move away from a worksite, or for a family health crisis. The change restricted the freedom to exit and compromised household reproduction strategies. The mass mobilisation that followed in Bangalore was portrayed as 'spontaneous' (Shridar 2016), but among an estimated half million garment workers in the city around 5 per cent belonged to one of two independent unions, which were relatively well represented in the factory where the mobilisation began (interview, Bangalore, May 2016). In other words the mobilisation was not discrete from longer-term processes of conscientisation. In a sector with a rapid turnover of workers (CWM n.d., 40), and an absence of mass membership, smaller groupings of union activists showed their capacity to channel moments of intensified antagonism into a successful direct confrontation that gathered structural power not only from their own location in one of the state's main export industries, but also from their physical proximity to the influential IT sector. When the garment workers poured out of their factories they closed down three of the city's largest roads. With many IT workers unable to reach their offices, the risk of international ramifications pressed the government into a u-turn.

The ability of a core of politicised workers to lie low as 'latent associational power' until moments when mobilisation becomes possible appears to be a key feature of the organisation of informal workers under late neoliberalism where fragmentation, precarity and the scarcity of work all undermine the capacity for sustained organisation. Forms of action inevitably have to diversify out from traditional patterns of unionism anchored in mass membership and sustained campaigns.

\section{Conclusion}

Much of the recent literature on the organisation of informal labour has focused on where it has relatively more structural power. This paper has argued for a heightened focus on highly fragmented classes of labour with less structural power. It has combined analysis of workplace divisions, patterns of integration into capitalist accumulation, and spatial fragmentation across 'reproduction zones', and then sought out possible bases for unity and likely forms of collective action. In other words, it has tried to map actual and potential structural and associational power by analysing how local labour control regimes vary across reproduction zones.

By comparing two contrasting reproduction zones the paper has highlighted the interrelations between different parts of the reproduction process and different moments of possible 
collective action. Within those reproduction zones, it has identified which groups along the continuum of informal classes of labour are more likely to mobilise, over what, where, and in relation to whom, and located that question on the broader terrain of the capital-labour relation in its more concrete and general forms. Worker unity, geographies of dependence on capital, the distribution of scarce skills, capital vulnerability, and the 'positionality' of maistries were all identified as important variables. The paper found pockets of actual and potential collective action among more skilled and less dependent workers, among somewhat less fragmented workers working on larger production sites for better-known employers, and with regards to state mediation of the capital-labour relation.

Informality and the heightened temporal and spatial fragmentation of labouring class reproduction are reflected in forms of self-organisation that are sporadic and emerge from often submerged networks in workplaces and living spaces, and through interactions with more visible allies. Collective action by informal labour is uneven and limited in scope, but this does not mean that the politics of classes of labour are not dynamic, nor does it mean that research that is grounded in the concrete, and situated in the broader context of antagonistic capitalist development, will not identify trends and routes to scaling up, extending and consolidating collective action.

\section{References}

Agarwala, R, 2013. Informal Labour, Formal Politics and Dignified Discontent in India. Cambridge: Cambridge University Press.

Baglioni, E and Campling, L. 2017. "Natural Resource Industries as Global Value Chains: Frontiers, Fetishism, Labour and the State". Environment and Planning A 49(11):2437-2456.

Banaji, J. 1994. "The Farmers' Movements: A Critique of Conservative Rural Coalitions”. Journal of Peasant Studies 21(3-4):228-245.

Barrientos, S, 2013. "Labour Chains: Analysing the Role of Labour Contractors in Global Production Networks". Journal of Development Studies 49(8): 1058-71.

Barrientos, S., \& Kritzinger, A. 2004. "Squaring the circle - global production and the informalisation of work in South African fruit exports". Journal of International Development 16(1):81-92.

Bernstein, H. 2006 "Is there an agrarian Question in the Twenty-First Century?" Canadian Journal of Development Studies 27(4): 449-460.

Borras, J, Hall, R, Scoones, I, White, B, and Wolford, W. 2011. "Towards a Better Understanding of Global Landgrabbing: An Introduction". Journal of Peasant Studies 38(2): 209-216.

Breman, J, 1996. Footloose Labour: Working in India's Informal Economy. Cambridge: Cambridge University Press.

Brookes, M. 2017. "Labour as a Transnational Actor: Alliances, Activism and the Protection of Labour Rights in the Philippines and Pakistan". Development and Change 48(5). 
Burawoy, M. 1985. The Politics of Production: Factory Regimes under Capitalism and Socialism. London: Verso.

Burawoy, M, 2010. 'From Polanyi to Pollyanna: The False Optimism of Global Labor Studies', Global Labour Journal 1(2):301-313.

Centre for Workers Management [CWM], n.d. 'Wages and Work Intensity: Study of the Garment Industry in Greater Bangalore’. Bangalore: CWM.

De Neve, G, 2014. "Entrapped Entrepreneurship: Labour Contractors in the South Indian Garment Industry”. Modern Asian Studies 48(5):1302-1333.

Government of India (NSSO). 2013. Key Indicators of Employment and Unemployment in India 2011-12. New Delhi: NSSO.

Government of India, 2017. Economic Survey 2016-17. New Delhi: Ministry of Finance Department of Economic Affairs Economic Division.

Harriss, J, Jeyaranjan, J, and Nagaraj, K. 2011. "Land, Labour and Caste Politics in Rural Tamil Nadu in the Twentieth Century: Iruvelpatu". Economic and Political Weekly 45(31)4761.

Harriss-White, B. 2005. "Poverty and Capitalism". Queen Elizabeth Hall Working Paper No. 134. Oxford: QEH, University of Oxford.

Harvey, D, 1982. The Limits to Capital. London and New York: Verso.

Kapadia, K, 1995. Siva and her Sisters: Gender, Caste and Class in Rural South India. Boulder: Westview.

Lerche, J, 2010. "From 'rural labour' to 'classes of labour': class fragmentation, caste and class struggle at the bottom of the Indian labour hierarchy" in The Comparative Political Economy of Development: Africa and South Asia, edited by B. Harriss-White and J. Heyer. London: Routledge.

Levien, M. 2011. "Special Economic Zones and Accumulation by Dispossession in India". Journal of Agrarian Change 11(4):454-483.

Marx, K, 1976 [1867]. Capital: A Critique of Political Economy Volume 1. London: Penguin.

Merk, J, 2009. "Jumping Scale and Bridging Space in the Era of Corporate Social Responsibility: Cross-Border Labour Struggles in the Global Garment Industry". Third World Quarterly 30(3):599-615.

Mezzadri, A, 2016. The Sweatshop Regime: Labouring Bodies, Exploitation and Garments made in India. Cambridge: Cambridge University Press.

Milkman, R. 2010. "Introduction" in Working for Justice: The LA Model of Organizing and Advocacy, edited by R. Milkman, J. Bloom and V. Narro. Ithaca: Cornell University Press. 
Milne, S. 2015. "Cambodia's Unofficial Regime of Extraction: Illegal Logging in the Shadow of Transnational Governance and Investment". Critical Asian Studies, 47(2):200228.

Moore, J, 2015. Capitalism in the Web of Life: Ecology and the Accumulation of Capital. London and New York: Verso.

Patnaik, U, 1976. "Class Differentiation within the Peasantry: an approach to analysis of Indian agriculture”. Economic and Political Weekly 11(39):A82-101.

Pattenden, J. 2005. "Trickle-down solidarity, globalisation and dynamics of social transformation in a south Indian village". Economic and Political Weekly 40(19): 1975-1985.

Pattenden, J. 2011. "Gatekeeping as accumulation and Domination: evidence from South India". Journal of Agrarian Change 11(2): 164-194

Pattenden, J. 2016a. Labour, State and Society in Rural India: A Class-Relational Approach. Manchester: Manchester University Press.

Pattenden, J. 2016b. "Working at the Margins of Global Production Networks: Local Labour Control Regimes and Rural-Based Labourers in South India". Third World Quarterly 37(10):1809-1833.

Poulantzas, N. 1978. State, Power, Socialism. London: Verso.

Rawal V. 2008. "Ownership holdings of land in rural India: putting the record straight". Economic and Political Weekly 43(10): 43-47.

Riisgaard, L, and Hammer, N. 2011. "Prospects for Labour in Global Value Chains: Labour Standards in the Cut Flower and Banana Industries". British Journal of Industrial Relations 49(1): $168-190$.

Scott, J. 1985 Weapons of the Weak: Everyday Forms of Peasant Resistance. New Haven: Yale University Press.

Scott, J. 1990. Domination and the Arts of Resistance: Hidden Transcripts. New Haven: Yale University Press.

Selwyn, B. 2014. The Global Development Crisis. Cambridge: Polity.

Silver, B. 2003. Forces of Labour: Workers' Movements and Globalization since 1870. Cambridge: Cambridge University Press.

Srija, A and Shirke, S, 2014. "An Analysis of the Informal Labour Market in India". Economy Matters (A Journal of the Confederation of Indian Industry). September-October 2014:40-46.

Srivastava R, 2012. "Changing employment Conditions of the Indian Workforce and Implications for Decent Work". Global Labour Journal 3(1):63-90. 
Srivastava, R and Jha, A. 2016. "Capital and Labour Standards in the Organised Construction Industry in India”, Project Report No. 2. London: SOAS.

Swider, S, 2015. Building China: Informal Work and the New Precariat. Ithaca: Cornell University Press.

Van der Loop, T. 1996. Industrial Dynamics and Fragmented Labour Markets: Construction Firms and Labourers in India. Thousand Oaks, Ca.: Sage.

Vijayabaskar, M, 2016. "State Spatial Restructuring, Subnational Politics and Emerging Spaces of Engagement for Collective Action: Labour Regimes in Tamil Nadu, Southern India". Environment and Planning C 0(0):1-15.

Waterman, P. 1993. "Social Movement-Unionism: A New Union Model for a New World Order”. Review 16(3):246-278.

Wetlesen, A. 2016. Local Labour Regimes and the Agency of Construction Workers in Chennai, South India. PhD Thesis. Oslo: University of Oslo.

Wilson, K. 1999. "Patterns of Accumulation and Struggles of Rural Labour". Journal of Peasant Studies 26(2-3):316-354.

Wright, E.O. 2000. "Working-Class Power, Capitalist-Class Interests and Class Compromise". American Journal of Sociology 105(4): 957-1002.

Zajak, S, 2017. "International Allies, Institutional Layering and Power in the Making of Labour in Bangladesh”. Development and Change 48 (5): 1007-1030.

Zajak, S, Egels-Zanden, N, and Piper, N, 2017. "Networks of Labour Activism: Collective Action Across Asia and Beyond. An Introduction to the Debate". Development and Change 48(5): 899-921. 